\title{
PEMBERDAYAAN MASYARAKAT PETANI JAGUNG (Zea mays L.) MELALUI PENGEMBANGAN KELOMPOK USAHA BERSAMA (KUBE) MELATI
}

\author{
Syam S. Kumaji ${ }^{*}$, Abubakar Sidik Katili ${ }^{1}$ \\ ${ }^{1 *}$ Program Studi Biologi, Fakultas Matematika dan Ilmu Pengetahuan Alam, Universitas Negeri Gorontalo, \\ Gorontalo, Indonesia \\ *Penulis Korespondensi: syamskumaji@ung.ac.id
}

\begin{abstract}
Abstrak
Implementasi program pemberdayaan masyarakat melalui pengolahan jagung melalui kegiatan KKN PPM tahun 2019 dilaksanakan di desa Ilohungayo. Adapun tujuan dari program ini adalah menyerap tenaga kerja, menambah pendapatan masyarakat melalui Usaha Kecil Menengah, meningkatkan kreativitas dan inovasi lokal yang dapat dijadikan produk khas daerah Gorontalo dan meningkatkan nilai jual komoditas Jagung di Desa Ilohungayo, Kecamatan Batudaa Kabupaten Gorontalo. Solusi yang dapat dilakukan yaitu melalui pengolahan bahan mentah jagung menjadi produk yang lezat, bergizi dan disukai serta bisa menjadi produk khas daerah yang dapat bersaing dengan daerah lain. Adapun metode yang digunakan dalam program ini adalah metode penyuluhan dan pelatihan. Program ini bekerja sama dengan KUBE Melati Desa Ilohungayo sebagai mitra dalam pusat pengolahan jagung menjadi stik jagung dan Plaza Amanda Jaya Gorontalo sebagai mitra dalam proses pemasaran produk cemilan. Alur kegiatan meliputi tahap persiapan berupa observasi ke dinas instansi terkait dan pembekalan mahasiswa KKN-PPM. Kemudian tahap pelaksanaan, yaitu penyuluhan dan pelatihan pada masyarakat di 4 dusun yakni Dusun Ilito, Ilito Barat, Hungayo, Hungayo Timur, dan Hungayo Selatan yang berpusat di Desa Ilohungayo.
\end{abstract}

Kata Kunci: Pemberdayaan, Produk, Jagung.

\begin{abstract}
The Implementation of a community service program through the processing of corn through the community service program 2019 is conducted at Ilohungayo Village. This program aims to absorb labors, add community income through small and medium enterprises, improve creativity and local innovation that can be the typical products from Gorontalo and increase the selling value of corn commodities at Ilohungayo Village, Batudaa Sub-district, Gorontalo District. The solution that can be done is through the processing of the raw corn into the delicious, nutritious and preferredproduct as well as to be the typical local product that can compete with products from other areas. The methods used in this program are counseling and training. This program cooperates with Melati joint venture at Ilohungayo village as a partner in the center of corn processing into corn stick as well as Plaza Amanda Jaya Gorontalo as a partner in the marketing process of the snack products. The flow of activities includes a preparation phase in the form of observation to the related institutions and students' Community Service Program briefing. The next phase is implementation which is counseling and training to the community at 4 orchards; Ilito Orchard, Ilito Barat, Hungayo, Hungayo Timur, and Hungayo Selatan which centered on Ilohungayo Village.
\end{abstract}

Keywords: Empowerment, Product, Corn.

\section{PENDAhuluan}

Gorontalo merupakan salah satu provinsi penghasil jagung utama di Indonesia. Hasil produksi jagung daerah Gorontalo telah di ekspor ke beberapa negara, antara lain Filipina, Malaysia, dan Korea Selatan. Selain untuk bahan baku pakan dan industri, jagung juga bisa diproduksi menjadi produk bernilai ekonomi.Warga Desa Ilohungayo, Kecamatan Batudaa,
Kabupaten Gorontalo itu mencoba peruntungan dengan memproduksi cemilan dari bahan baku jagung. 


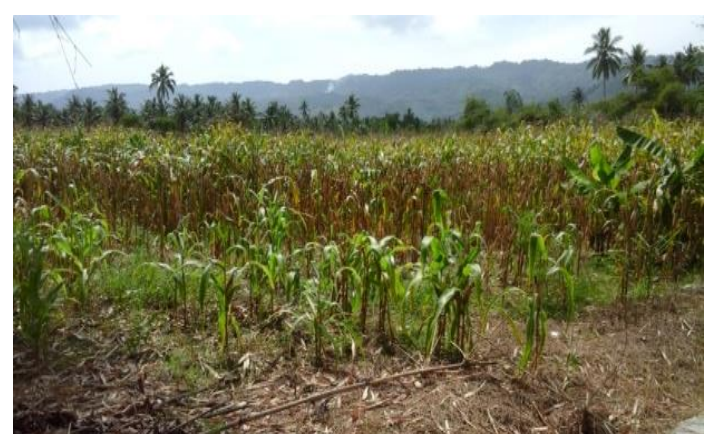

Gambar 1. Potensi Jagung Desa Ilohungayo.

Desa Ilohungayo merupakan salah satu Desa dari 8 Desa yang berada di kecamatan Batudaa, yang berdasarkan letak geografis berada disebelah barat dari Desa Payungga dengan luas $\pm 910 \mathrm{Ha}$. Dengan kondisi Tofografi alam Desa Ilohungayo, sebagaimana di desadesa lain mempunyai iklim kemarau dan penghujan. Desa Ilohungayo terbagi dalam 4 Dusun yaitu Dusun Ilito, Dusun Ilito Barat, Dusun Hungayo, Dusun Hungayo Timur, dan Dusun Hungayo Selatan. Pada aspek demografis, tahun 2009 Desa IlohungayoDusun Ilito, Ilito Barat, Hungayo, Hungayo Timur, dan Hungayo Selatan memiliki penduduk sejumlah 2630 jiwa, dan tahun 2010 naik sebesar 1,07\% sejumlah 2658. Keadaan perekonomian di Desa Ilohungayo lebih didominasi oleh sektor pertanian dan nelayan. Dari data yang ada, lahan pertanian yang ada di desa ini adalah seluas 113 Ha diwilayah Dusun Ilito, Dusun Ilito Barat, Dusun Hungayo, Dusun Hungayo Timur, dan Dusun Hungayo Selatan. Tanaman jagung (Zea mays L.) merupakan salah satu tanaman biji-bijian dari keluarga rumput-rumputan (Graminae).

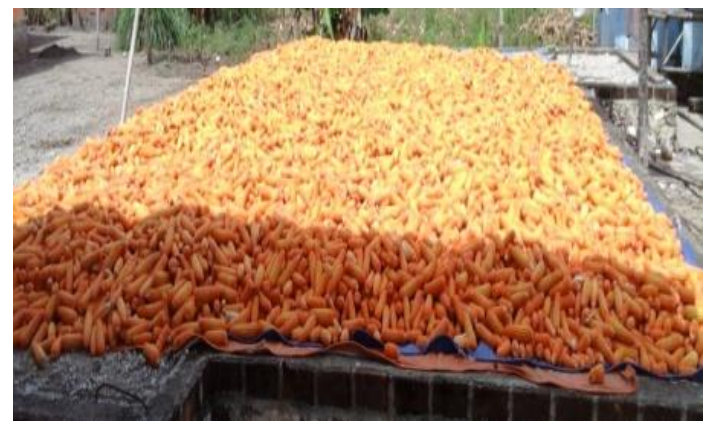

Gambar 2. Hasil Panen Jagung.

Jagung adalah salah satu tanaman pangan penghasil karbohidrat yang terpenting di dunia. Bagian jagung yang biasa dimakan manusia adalah bijinya, baik masih muda ketika isinya belum mengering maupun setelah tua dan mengering. Biji jagung kaya akan karbohidrat. Sebagian besar berada pada endosperma. Kandungan karbohidrat dapat mencapai $80 \%$ dari seluruh bahan kering biji. (Merdiyanti, 2008).

Retno (2009) menambahkan Jagung merupakan tanaman semusim (annual). Satu siklus hidupnya diselesaikan dalam 80-150 hari. Paruh pertama dari siklus merupakan tahap pertumbuhan vegetatif dan paruh kedua untuk tahap pertumbuhan generatif.
Tanaman jagung merupakan salah satu jenis tanaman pangan biji-bijian (serelia) dari keluarga rumputrumputan. Menurut Suprapto dan Marzuki (2005), jagung yang banyak ditanam di Indonesia adalah tipe mutiara (flint) dan setengah mutiara (semiflint), seperti jagung Arjuna (mutiara), jagung Harapan (setengah mutiara), Pioneer-2 (setengah mutiara), Hibrida C-1 (setengah mutiara), dan lain-lain. Selain jagung tipe mutiara dan setengah mutiara, jagung tipe berondong (pop corn), jagung gigi kuda (dent corn), dan jagung manis (sweet corn) juga terdapat diIndonesia.

Boyer dan Shannon (2003) menambahkan, komponen kimia terbesar dalam biji jagung adalah karbohidrat (72\% dari berat biji) yang sebagian besar berisi pati dan mayoritas terdapat pada bagian endosperma. Endosperma matang terdiri dari $86 \%$ pati dan sekitar $1 \%$ gula. Pati terdiri dari dua polimer glucan, yaitu amilosa dan amilopektin. Secara umum, pati jagung mengandung amilosa sekitar 25-30\% dan amilopektin sekitar 70-75\%. Gula dalam biji jagung terdapat dalam bentuk monosakarida (Dglukosa dan D fruktosa), disakarida dan trisakarida, serta gula alkohol. Sukrosa merupakan disakarida terbanyak dalam biji jagung (2-3 mg perendosperma). Sedangkan maltosa, trisakarida, dan oligosakarida terdapat dalam jumlah sedikit. Adapun phytate (hexaphosphoric ester dari myoinositol) diketahui sebagai satu-satunya gula alkohol yang terdapat dalam biji jagung. Sekitar 90\% phytate ditemukan di dalam skutelum dan 10\%-nya terdapat di dalam aleuron (Boyer dan Shannon, 2003).

Pada tahun yang sama Watson (2003) menemukan biji jagung juga mengandung beberapa vitamin seperti kolin $(567 \mathrm{mg} / \mathrm{kg})$, niasin $(28 \mathrm{mg} / \mathrm{kg})$, asam pantotenat $(6,6$ $\mathrm{mg} / \mathrm{kg})$, piridoksin $(5,3 \mathrm{mg} / \mathrm{kg})$, tiamin $(3,8 \mathrm{mg} / \mathrm{kg})$, riboflavin $(1,4 \mathrm{mg} / \mathrm{kg})$, asam folat $(0,3 \mathrm{mg} / \mathrm{kg})$, biotin $(0,08 \mathrm{mg} / \mathrm{kg})$, serta vitamin A (karoten) dan vitamin $\mathrm{E}$ (tokoferol) masing-masing sebesar $2,5 \mathrm{mg} / \mathrm{kg}$ dan 30 IU/kg. Retno (2009) melakukan penelitian mendalam tentang Jagung. Di Indonesia dikenal 2 (dua) varietas jagung yang telah ditanam secara umum, yaitu jagung berwarna kuning dan putih. Kedua varietas tersebut bagian yang kaya akan karbohidrat adalah bagian biji. Sebagian besar karbohidrat berada pada endospermium. Kandungan karbohidrat dapat mencapai $80 \%$ dari seluruh bahan kering biji. Karbohidrat dalam bentuk patin umumnya berupa campuran amilosa dan amilopektin. Pada jagung ketan, sebagian besar atau seluruh patin yang merupakan amilopektin (Suarni, 2009).

Desa Ilohungayo merupakan salah satu daerah yang memiliki potensi Jagung yang cukup luas dengan sebagian besar komoditas pertaniannya adalah Jagung. Seperti yang diungkapkan oleh Kepala Desa di Desa Ilohungayo, mengatakan bahwa Produksi Jagung untuk musim tanam I = 94.761 Ton. Produksi Jagung di Gorontalo terbilang besar komoditasnya. Tetapi untuk meningkatkan nilai jual Jagung dan meningkatkan kesejahteraan para petani maka perlu dilakukan industri 
dalam bidang pangan dan ekonomi kreatif. Selama ini bahan baku Jagung di Gorontalo hanya dimanfaatkan untuk bahan dasar makanan khas Gorontalo yakni Binthe Biluhuta. Selain itu, bahan baku Jagung diekspor ke beberapa negara seperti Filipina, Malaysia, dan Korea Selatan meningkat tiap tahunnya, tetapi yang di ekspor hanya berupa bahan mentah, dan hal tersebut tidak dapat meningkatkan nilai jual Jagung. Sesuai hasil wawancara dengan para petani Jagung di desa Ilohungayo, semua petani mengatakan bahwa hasil panen Jagung dijual langsung dipasar-pasar tradisional dengan harga tergolong rendah. Harga cenderung rendah salah satu sebabnya minimnya kreativitas dan inovasi lokal yang dapat dijadikan produk khas daerah Gorontalo.

Minimnya intervensi teknologi pengolahan belum memberi nilai tambah produk jagung. Padahal jagung bisa diandalkan menjadi kompetensi inti industri Gorontalo. Permintaan beberapa negara seperti Malaysia, Philipina, Jepang dan Korea juga cenderung meningkat. Akibat minimnya kreativitas dan inovasi lokal membuat sulit untuk menemukan produk industri berbasis jagung yang dapat dijadikan produk khas daerah. Dengan memanfaatkan teknologi produksi pertanian jagung sebenarnya dapat dimanfaatkan menjadi peluang usaha mikro, kecil dan menengah (UMKM) terutama bagi mahasiswa yang mau dan mampu merintis usaha (Mopangga dkk, 2013:195).

Dari uraian diatas, terlihat bahwa masalah utamanya yaitu terdapat pada tingkat kreatifitas produksi yang masih tergolong rendah. Hal ini dikarenakan para Petani Jagung hanya menjual produknya berupa bahan mentah Jagung langsung ke pasar tradisional. Adapun solusi yang ditawarkan adalah dengan mengolah buah Jagung menjadi olahan makanan berupa Stik Jagung dan tentunya memiliki nilai jual yang cukup berkompeten. Menyiasati minimnya jenis usaha produk olahan makanan yang memanfaatkan jagung maka terdapat sejumlah orang yang telah memiliki sedikit pengalaman dalam pengolahan stik, emping dan kerupuk berinisiatif membuat stik jagung. Pembuatan stik jagung ini tentu saja dengan harapan agar segera terealisasi usaha tersebut. Bisnis yang akan didirikan ini adalah usaha pengolahan pangan berbasis jagung menjadi produk makanan ringan yaitu stik jagung ikan. Usaha ini dibentuk untuk memanfaatkan komoditas terbesar dan unggulan Gorontalo yaitu jagung sehingga dapat diolah menjadi produk yang lebih bernilai tambah dan bergizi tinggi sekaligus menjadi ole-ole khas Gorontalo.

Jenis usaha kecil yang potensial, terus meningkat dan menjadi peluang bagi calon wirausaha di Gorontalo adalah bisnis jasa, eceran, distribusi, agribisnis/pertanian, dan bisnis manufaktur. Kontirbusinya signifikan bagi pengurangan pengangguran, penciptaan lapangan kerja dan pendapatan di Gorontalo (Niode, 2007:99). Rasa khas yang unik dari jagung dalam stick jagung ini sangat terasa sekali, juga nutrisi serta manfaat jagung dalam stick jagung ini tetap terjaga kandungannya. Kandungan yang terdapat dalam stik jagung ini sangat banyak mulai dari karbohidrat, serat, vitamin, kalium, asam linoleat, asam folat, beta karoten, mineral, protein dan lain-lain. Selain itu stik jagung juga memberikan manfaat bagi kesehatan diantaranya dapat melawan kanker, dapat mencegah anemia dan sebagai sistem imun, untuk mengatasi infeksi saluran kemih, mencegah batu ginjal dan menurunkan kadar asam urat, mengendalikan kadar kolesterol, meningkatkan aliran darah dalam tubuh, kesehatan mata dan kulit, dapat memberi rasa kenyang lebih lama.

Pengolahan Jagung menjadi Cemilan ini di Sosialisasikan melalui Kegiatan Kuliah Kerja Nyata Pembelajaran dan Pemberdayaan Masyarakat (KKNPPM) oleh Lembaga Penelitian dan Pengabdian Masyarakat (LPPM) Universitas Negeri Gorontalo (UNG). Kegiatan ini berupa Penyuluhan dan Pelatihan pembuatan Stik Jagung oleh Dosen dan Mahasiswa UNG terhadap masyarakat Desa Ilohungayo. Adanya partisipasi langsung masyarakat ini diharapkan dapat mengembangkan pengolahan buah Jagung sehingga kegiatan ini dapat berkelanjutan.

Dalam pelaksanaan kegiatan yang diusulkan ini, yang menjadi Mitra dalam kegiatan adalah Lembaga Kelompok Usaha Bersama (KUBE) Melati Desa Ilohungayo Kecamatan Batudaa Kabupaten Gorontalo. Adapun profil Kelompok Usaha Bersama (KUBE) Melati Desa Ilohungayo.

Kelompok Usaha Bersama (KUBE) Melati Desa Ilohungayo adalah Kelompok sosial masyarakat yang berkenaan dengan segala aktivitas pengolahan hasil pertanian di desa Ilohungayo yang berdiri dari Tahun 2007 dan diketuai oleh ibu Aisyah Poiyo. Adapun kelompok sasaran dalam kegiatan ini adalah masyarakat petani jagung dan kelompok pembuat kue di Desa Ilohungayo. Melalui Observasi lapangan, rata-rata Masyarakat Petani jagung memiliki kondisi perekonomian yang tergolong cukup rendah. Melalui kegiatan ini, diharapkan dapat mendongkrak ekonomi Masyarakat Petani melalui pengolahan labu jagungmenjadi Cemilan Stik Jagung yang akan dipasarkan baik melalui pasar tradisional maupun tokotoko yang berada di provinsi Gorontalo. 


\section{BAHAN DAN METODE}

Alur pelaksanaan kegiatan dapat dilihat seperti pada diagram dibawah ini :

\begin{tabular}{|c|}
\hline $\begin{array}{c}\text { Koordinasi Tim, dengan Dinas Instansi } \\
\text { terkait dan Pemerintah dan Kelompok }\end{array}$ \\
\hline $\begin{array}{c}\text { Kegiatan inti sosialisasi dan pelatihan } \\
\text { pengolahan jagung menjadi cemilan }\end{array}$ \\
\hline $\begin{array}{c}\text { Monitoring dan evaluasi pembuatan, } \\
\text { distribusi dan hasil pemasaran stik jagung }\end{array}$ \\
\hline $\begin{array}{c}\text { Hasil pengabdian meningkatkan ekonomi } \\
\text { masyarakat petani jagung }\end{array}$ \\
\hline
\end{tabular}

Gambar 3. Alur pelaksanaan Program KKN PPM Desa Ilohungayo 2019.

Bentuk program yang dilaksanakan adalah program produksi/pengolaan produk Jagung Higienis.

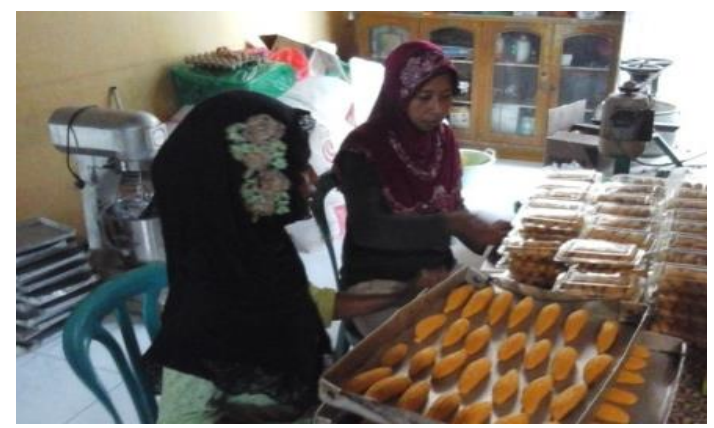

Gambar 4. Pengolahan Jagung.

Metode yang digunakan dalam pemberdayaan kelompok sasaran adalah pembelajaran teknik membuat Stik Jagung yang berkualitas disertai teori dan praktek langsung. Pembelajaran disertai praktek akan dilakukan oleh mahasiswa bersama-sama dengan kelompok sasaran yang juga didampingi oleh mitra yang professional di bidangnya.

Alat yang digunakan pada pengolahan kue kering (cemilan) berbahan dasar Jagung ini yaitu Gilingan, Belanga goreng, Tirisan, Loyang besar, Baki besar, Baki kecil, Sendok besar, Panci, Kompor, Alat penggiling, Kompor, Wajan, Tirisan., siler, timbangan dan plastik polietilen. Bahan yang diperlukan untuk cemilan : 1) Jagung, 2) Tepung terigu protein, 3) Tepung, 4) Gula pasir, 5) Minyak goreng, 6) Bawang putih, 7) Telur, 8) Garam secukupnya. Prosedur kerja Pembuatan stik jagung meliputi : 1) Siapkan semua bahan yang akan digunakan, 2) Rebus jagung yang sudah dicuci bersih dalam panci sampai matang, 3) Setelah jagung masak angkat dan ditiriskan, 4) Menggiling tipis di gilingan mi ketebalan paling besar 2 tiga kali, lalu campur dengan telur, bawang putih, dan gula pasir, kemudian kecilkan lubang gilingan mie nya, giling lagi hingga 2 kali sampai halus. Taburi sedikit sagu di adonan agar tidak lengket waktu menggiling., 5) Memotong dengan pemotong mie yang lebar, 6) Menggoreng di minyak panas dan terendam sampai renyah dan matang, 7) Meniriskan gorekan apabila sudah benar-benar matang dan berubah warna menjadi kuning kecoklatan, 8) Mengemas dan melabel gorengan yang sudah didinginkan, 9) Metode yang digunakan yaitu metode observasi partisipatif terhadap objek dimana penulis mengamati dan terlibat langsung dalam setiap langkah kerjanya. Disamping itu dilakukan wawancara dengan pembimbing lapangan serta karyawan yang bekerja dilokasi pengamatan.

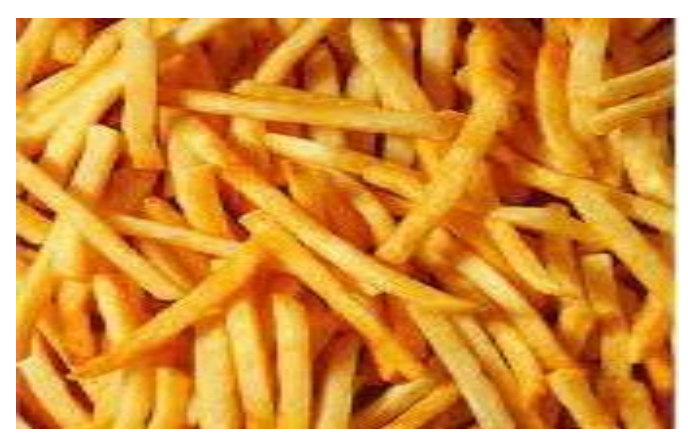

Gambar 5. Hasil Olahan Jagung.

\section{HASIL DAN PEMBAHASAN}

Kegiatan bimbingan teknis pengolahan jagung menjadi ragam produk cemilan yang sehat dan higienis telah dilaksanakan di desa Ilohungayo. Secara rinci materi yang diberikan adalah:

1. Materi Pertama: Potensi Jagung dan Berbagai Permasalahan yang dihadapi Petani di Desa Ilohungayo Kecamatan Batudaa Kabupaten Gorontalo. Materi ini mengungkapkan berbagai potensi ril yang dimiliki desa salah satunya jagung yang banyak dibudidayakan di wilayah ini. Disamping itu pula diuraikan secara rinci berbagai masalah yang dihadapi oleh petani dan kelompok masyarakat pengolah jagung, baik masalah produksi dan pemasaran. 1) Masalah produksi: tingginya jumlah panen dari waktu ke waktu dan belum mampu memberikan manfaat ekonomi yang tinggi bagi masyarakat setempat. Solusi konkrit yang ditawarkan adalah : membuat ragam produk hasil olahan bahan baku jagung. 2) Masalah pemasaran : melaksanakan pemetaan kebutuhan ragam produk olahan jagung di tingkat wilayah kecamatan maupun tingkat daerah, membuat kontrak penjualan dengan mitra pemasaran, serta pemasaran langsung pada konsumen. Hasil implementasinya solusi diharapkan mampu memberikan nilai manfaat dalam meningkatkan kesejahteraan petani dan kelompok masyarakat setempat sebagai pengolah ragam produk cemilan jagung.

2. Materi Kedua: Sinergi Pemeritah dan Perguruan Tinggi Universitas Negeri Gorontalo dengan Masyarakat Dalam Upaya Pemberdayaan dan 
Peningkatan Kesejahteraan Kelompok Petani dan pengolah jagung. Materi ini menegaskan pentingnya peran perguruan tinggi Universitas Negeri Gorontalo dalam mengiplementasikan program Tri Dharma Perguruan Tinggi, khususnya pengabdian masyarakat. Sebagai lembaga tinggi yang mengembangan ilmu pengetahuan dan teknologi maka mutlak dibutuhkan peran perguruan tinggi dalam mengangkat dan mengembangkan potensi wilayah, khususnya potensi jagung yang melimpah di desa Ilohungayo Kecamatan Batudaa Kabupaten Gorontalo. Masalah yang dihadapi adalah : 1) Belum maksimalnya kajian potensi unggulan berbasis pedesaan sebagai dasar dalam penerapan iptek dan program pembangunan pedesaan. Solusi konkrit yang ditawarkan adalah : melaksanakan kerjasama riset eksploitasi potensi unggulan berbasis pedesaan. Hasil yang diharapkan adalah : adanya hasil riset unggulan berbasis desa sebagai dasar dalam melaksanakan hilirisasi riset secara berkelanjutan, 2) Masih kurangnya hilirisasi hasil riset untuk meningkatkan kesejahteraan masyarakat. Solusinya konkrit yang ditawarkan adalah : membuat kerjasama kemitraan antara perguruan tinggi Universitas Negeri Gorontalo dengan desa binaan untuk eksploitasi dan pengembangan potensi unggulan desa. Hasil yang diharapkan adalah : meningkatnya peran perguruan tinggi dalam penerapan iptek sebagai salah satu upaya dalam meningkatkan kesejahteraan masyarakat.

3. Materi Ketiga: Pembelajaran Aspek Hukum Dalam Bisnis. Materi ini menegaskan akan pentingnya mempertimbangkan aspek hukum dalam bisnis melalui tindakan-tindakan yang tidak bertentangan dengan hukum baik secara pidana maupun perdata. Secara pidana yang harus diperhatikan misalnya tentang jaminan kandungan produk cemilan yang tidak mengandung bahan berbahaya yang dapat berakibat pada gangguan kesehatan hingga kematian pada konsumen. Sedangkan secara perdata misalnya tentang pentingnya penggunaan merk dagang secara mandiri tanpa melalui duplikasi dari produk lain. Disamping itu pula diperhatikan tentang aspek Hak Kekayaan Intelektual yang mungkin saja dapat dimiliki oleh kelompok pengrajin sebagai karya orisinal yang perlu memperoleh hak paten. Hasilnya menunjukkan: meningkatnya pemahaman anggota kelompok tentang pentingnya aspek hukum dalam bisnis sehingga dapat menjalankan operasional bisnis tanpa melakukan pelanggaran hukum baik secara pidana maupun perdata.

4. Materi Kelima: Teori dan Praktek Penyusunan Studi Kelayakan Bisnis Cemilan jagung Bagi Kelompok Masyarakat Pengrajin. Pada materi ini anggota kelompok sasaran memperoleh pengetahuan dan pengalaman bagaimana menyusun program kerja yang realistis berdasarkan kondisi internal dan kondisi eksternal yang dihadapi oleh kelompok pengrajin pada masa sekarang dan perencanaan bisnis jangka panjang. Pengalaman tersebut meyakinkan anggota kelompok tentang prospek bisnis yang menjanjikan dan pasti untuk produk cemilan jagung yang direncanakan secara realistis, terencana dan sistematis. Dalam materi ini juga dipraktekkan tentang penyusunan rencana bisnis secara periode bulanan dan tahunan. Praktek juga difokuskan pada penyusunan tahapan-tahapan dalam mencapai rencana secara periodik. Kegiatan lainnya adalah simulasi bagaimana menangani permasalahan yang muncul baik secara internal maupun eksternal dan bagaimana pula menghadapi lingkungan bisnis eksternal yang berubah dengan sangat cepat. Hasilnya menunjukkan: Terjadi peningkatan kemampuan kapasitas kelompok pengolah jagung dalam hal penyusunan rencana bisnis bulanan dan tahunan.

5. Materi Keenam: Praktek Inovasi Produk Cemilan jagung. Praktek untuk inovasi produk dilakukan oleh praktisi, dalam hal ini salah satu mitra yang memiliki pengetahuan dan pengalaman luas tentang produksi cemilan jagung sesuai dengan standarisasi pasar moderen. Semua peserta mengikuti dengan baik dan mempraktekkan inovasi tersebut untuk menghasilkan produk-produk terbaru tentang cemilan jagung. Inovasi dilakukan dalam bentuk cemilan aneka rasa yaitu rasa pedas, manis dan asin sebagai inovasi rasa baru untuk cemilan jagung. Inovasi tersebut juga merupakan peluang bagi kelompok usaha untuk memproduksi cemilan aneka rasa khas desa Ilohungayo.

Hasil kegiatan bimbingan teknis proses pembuatan cemilan jagung menjadi ragam produk yang sehat dan higienis di Desa Ilohungayo memberikan pengalaman dan penguatan terhadap anggota kelompok pengrajin akan besarnya potensi bisnis produk cemilan jagung. Disamping itu pula bimbingan teknis memberikan bekal pengetahuan manajemen pengolahan usaha beserta implementasinya pada kegiatan usaha. Hal penting lainnya dari bimbingan teknis adalah pengetahuan bagi kelompok usaha juga diberikan mengenai aspek hukum dalam usaha. Hal tersebut untuk memberikan jaminan kepastian hukum maupun legalitas terhadap usaha yang dijalankan, juga untuk memberikan pengetahuan tentang berbagai resiko yang mungkin saja terjadi dalam bisnis. Disamping itu pula peserta sebagai kelompok sasaran dibekali tentang kemitraan dengan pihak usaha lain, perencanaan pasar dan sebagainya. Kegiatan bimbingan teknis dilanjutkan pula dengan teori dan praktek penyusunan rencana binis bagi sektor usaha kecil menengah yang diikuti oleh seluruh peserta anggota kelompok.

\section{KESIMPULAN}

Melalui program KKN-PPM di Desa Ilohungayo tahun 2019 telah banyak memberikan pengetahuan dan pengalaman empirik bagi tim dosen pelaksana, mahasiswa dan utamaya bagi kelompok sasaran. 
Berbagai manfaat tersebut setidaknya dapat diuraikan sebagai berikut:

1) Mahasiswa mampu mengaplikasikan teori dalam praktek dari berbagai disiplin ilmu yaitu pertanian, ekonomi, ilmu pengetahuan alam dan ilmu hukum. Disamping itu pula bagi seluruh mahasiswa peserta sebagai perwujudan sikap positif dan produktif mahasiswa bersama kelompok pengolah jagung dan masyarakat pada umumnya di desa Ilohungayo. Mulai terbiasanya mahasiswa dengan sikap peduli, empati kepada masalah-masalah sosial di masyarakat, utamanya dalam masalah pemberdayaan masyarakat petani jagung dan kelompok masyarakat pengolah jagung.

2) Terwujudnya sinergi antara kelompok pengrajin dengan konsumen produk cemilan jagung pada wilayah sasaran dan sekitarnya. Pemerintah setempat telah terbantu dalam hal meningkatkan pemberdayaan masyarakat kelompok petani jagung dan kelompok pengolah cemilan jagung.

3) Kegiatan ini sebagai kontribusi nyata dari perguruan tinggi dan tim dosen pelaksana dalam hal implementasi keilmuan untuk menjawab masalah mendasar yang dihadapi oleh kelompok sasaran di desa Ilohungayo.

Berdasarkan implementasi dan hasil akhir kegiatan maka tim pelaksana mengusulkan beberapa aspek sebagai berikut:

1) Program KKN-PPM harus tetap diadakan dengan pada masa yang akan datang karena telah terbukti berkontribusi nyata bagi masyarakat, pemerintah desa, dosen, mahasiswa serta perguruan tinggi.

2) Program KKN-PPM perlu diperluas di berbagai wilayah terpencil untuk mengangkat berbagai potensi desa yang masih terpendam sebagai bentuk komitmen perguruan tinggi dalam program pengabdian kepada masyarakat.

3) Disarankan setelah selesainya kegiatan KKN-PPM 2019 dapat dikembangkan lagi melalui Program Kemitraan Wilayah (PKW) untuk terus menguatkan potensi jagung sebagai ragam produk cemilan yang sehat dan higienis khas desa Ilohungayo Kecamatan Batudaa Pantai Kabupaten Gorontalo.

\section{UCAPAN TERIMAKASIH}

Setelah melalui berbagai tahapan proses kegiaan KKNPPM Tahun 2019 maka hasil kegiatan ini telah memberikan manfaat bagi kelompok petani dan kelompok ibu-ibu sebagai sasaran. Disamping itu pula manfaat bagi pemerintah Desa, mahasiswa, dosen dan perguruan tinggi. Oleh karena itu pada kesempatan ini kami menyampaikan ucapan terimakasih disampaikan kepada 1) Direktorat jenderal pengabdian masyarakat Kementerian Ristek dan Dikti Republik Indonesia, 2) Pimpinan dan seluruh staf Lembaga Penelitian dan Pengabdian masyarakat Universitas Negeri Gorontalo, 3) Pemerintah Kabupaten Gorontalo, Kecamatan Batudaa Pantai dan pemerintah desa Ilohungayo, 4) Kelompok Petani jagung dan Ibu-ibu kelompok pengolah ragam produk cemilan Desa Ilohungayo, 5)
Tim pelaksana dan mahasiswa peserta KKN-PPM. Semoga hasil kegiatan pengadian ini mampu memberikan manfaat jangka panjang bagi kelompok petani dan pengolah jagung serta masyarakat sekitarnya.

\section{DAFTAR PUSTAKA}

Boyer, C.D., and J.C. Shannon. 2003. Carbohydrates of the kernel. In: White PJ., Johnson LA., editor. Corn: Chemistry and Technology. 2nd Ed. Minnesota: American Association Of Cereal Chemists Inc. St. Paul, Minnesota, USA

Merdiyanti, A. 2008. Paket Teknologi Pembuatan Mi Kering denganMemanfaatkan Bahan Baku Tepung Jagung. (Skripsi). IPB. Bogor

Retno, Ariyaningrum. 2009. Pelatihan Teknologi Olahan Bahan Pangan dari Bahan Dasar Jagung sebagai Alternatif Wirausaha bagi Masyarakat Kurang Mampu di Dusun Gembyong, NgoroOro, Kecamatan Patuk, Kabupaten Gunung Kidul. Yogyakarta : LPPMP UNY

Suarni. 2009. Prospek pemanfaatan tepung jagung untuk kue kering (cookies). Jurnal Litbang Pertanian. 28 (2)

Suprapto, \& Marzuki. 2005. Botani Tanaman Jagung. Sumatera Utara: Universitas Sumatera Utara Press.

Watson, S.A. 2003. Description, development, structure, and composition of the corn kernel. Di dalam: White PJ., Johnson LA., editor. Corn: Chemistry and Technology. 2nd Ed. Minnesota: American Association Of Cereal Chemists Inc. St. Paul, Minnesota, USA. 69-101. 